UDC 621.82

L. Berezin, PhD, Assoc. Prof.

Kyiv National University of Technologies and Design, 2 Nemyrovycha-Danchenka, Str., Kyiv, Ukraine, 01011; e-mail: Lnb07@ukr.net

\title{
CALCULATION OF SMALL-SIZED CYLINDRICAL COIL SPRINGS ON FATIGUE STRENGTH IN PROBABILISTIC FORMULATION
}

\begin{abstract}
Л.М. Березін. Розрахунок малогабаритних циліндричних гвинтових пружин за втомною міцністю в ймовірнісній постановці. Працездатність багатьох машин лімітується ресурсом циліндричних гвинтових пружин, який залежить від їх надійності за міцністю і стабільності силових характеристик. Розрахунки на міцність пружин регламентовані i, як правило, обмежуються традиційною перевіркою за коефіцієнтом запасу втомної міцності. Оскільки пружини відносять до деталей, які мають випадковість навантажень i характеристик міцності, очевидна доцільність перевірки пружин на надійність і довговічність за критерієм втомної міцності. Додаткова вимога щодо забезпечення обмежених, але достатніх, запасів міцності стосовно малогабаритних пружин також сприяє проведенню розрахунків в ймовірнісній постановці. Метою роботи є розробка методології універсального розрахунку малогабаритних циліндричних гвинтових пружин на надійність і довговічність за критерієм втомної міцності на основі узагальнення матеріалів нормативно-керівних документів, довідкової емпіричної та аналітичної інформації. Запропоновано алгоритм для визначення статистичних параметрів опору втоми пружин за дотичними напруженнями при відсутності або обмеженій базі вихідних даних. Обгрунтовано вибір коефіцієнтів для переходу від границі втоми матеріалу до відповідного параметру пружини з урахуванням оцінки його розсіювання. Розглянуто питання схематизації і статистичної обробки спектрів навантажень ступінчастого і безперервного виду для обчислення характеристик навантаженості пружин. Конкретизовано вибір значення коефіцієнта варіації навантаження стосовно пружин. Статистичні характеристики навантажень і опору втоми пружин використовували для оцінки ймовірності їх безвідмовної роботи і довговічності в імовірнісному аспекті. Наведено приклад розрахунку на міцність від утоми в ймовірнісній постановці циліндричної гвинтової пружини розтягу і стиску позиції 3663 урахуванням вимоги мінімізації розмірів.

Ключові слова: циліндрична гвинтова пружина; перевірний розрахунок; втомлена міцність; надійність; довговічність
\end{abstract}

L. Berezin. Calculation of small-sized cylindrical coil springs on fatigue strength in probabilistic formulation. The efficiency of many machines is limited by the resource of cylindrical coil springs, which depends on their strength reliability and stability of power characteristics. Strength calculations of springs are regulated and, as a rule, are limited to traditional testing by the margin factor of fatigue strength. Since springs are related to parts that have random loading and strength characteristics, the expediency of testing springs for reliability and longevity is obvious. The additional requirement for the provision of limited, but sufficient, strength margin with respect to small-sized springs also contributes to the calculations in a probabilistic formulation. The purpose of the work is to develop a methodology for the universal calculation of small-sized cylindrical helical springs for reliability and durability by the criterion of fatigue strength based on the generalization of materials of regulatory guidance documents, empirical and analytical information. An algorithm for determining the statistical parameters of spring fatigue resistance by tangential stresses in the absence or limited base of initial data is presented. The choice of coefficients for the transition from the material fatigue limit to the corresponding spring parameter is justified, taking into account the estimate of its variations. The problems of schematization and statistical processing of loading spectrum of a stepwise and continuous type to calculate the characteristics of the loading of springs are considered. Selection of the coefficient of variation of the load with reference to the springs is substantiated. Statistical characteristics of the loads and fatigue resistance of the springs were used to estimate their probability of failsafe operation and longevity in the probabilistic aspect. An example is given of the fatigue strength calculation in a probabilistic formulation of a cylindrical helical spring for stretching and compressing position 366, taking into account the requirement of minimizing sizes.

Keywords: cylindrical coil springs; checking calculation; fatigue strength; reliability; longevity

Introduction. The efficiency of many machines is limited by the resource springs, which depends on their strength reliability and stability of power characteristics. Cylindrical coil springs (hereinafter referred to as springs), working in tension and (or) compression, made of round cross-section bars, have received the greatest use. The design calculation of the springs is reduced to the determination of their geometrical parameters based on specified loads, working conditions and, if necessary, weight and overall dimensions. The issues of calculating and designing tension and compression springs are widely represented in the reference literature and open access sources.

Analysis of basic research and publications. Spring strength calculations based on the fatigue criterion in the traditional (deterministic) formulation have been developed sufficiently and are widely 
used in the packages ANSYS10.0, MATHCAD, SolidWorks, Pro-E, CATIA, Autodesk Inventor, in the environment of the Compass-3D V6 system (the Compass application spring) and others. Use traditional strength test for permissible stresses or normalized safety factor [1]. However, given that the springs have random loading and material strength characteristics, along with the requirement to ensure small but sufficient safety margins, it is obvious that the springs should be tested according to the fatigue strength criterion in a probabilistic formulation. In [2], a simplified approach is presented for estimating the probability of spring failure-free operation. Assumptions in the calculations are reduced to an arbitrary choice of the law of the distribution of the spring resource and the overall coefficient of variation, which takes into account the deviations of the material fatigue boundary and the amplitudes of the stresses in the spring section.

Thus, without the availability of relevant source information in the calculations rely on the experience of the designer. Spring modeling by the finite element method and multi-axis fatigue analysis are presented in [3]. However, it is difficult for the user to get a general idea of the change in the corresponding parameter. In addition, as for engineering calculation, it should be noted that calculations that are too cumbersome for manual counting, and in the case of the use of computer technology, the need to develop special programs. At the same time, discretization errors and approximations of the method as applied to springs impair convergence to the exact solution.

Evaluation of the fatigue longevity of large springs with the number of loading cycles $10^{7}$ and more, is presented in [4 -6]. Special cases based on numerical and experimental analysis narrow the use of the results as a general calculation methodology.On the issue of the influence of the choice of materials on the longevity of the springs, first of all, we should highlight studies of composite springs made of E-glass, epoxy resin, carbon [7 - 8]. Features of strength spring calculations, which are of a private nature depending on the purpose and special loading conditions, are presented for a number of following vehicles: cars [9], motorcycles, railway transport [10].

Taking into account the narrow focus of the articles on the topic, it is advisable to develop a methodological complex of engineering solutions for applied problems of assessing and ensuring fatigue longevity and spring reliability at the design stage.

Purpose of the study. In calculations for fatigue strength in probabilistic formulation (read reliability), the random values are the loads and the mechanical characteristics of the strength of the part. The aim of the work is to develop a methodology for the universal calculation of small-sized cylindrical helical springs for reliability and longevity by the criterion of fatigue strength based on the generalization of materials of regulatory guidance documents, empirical and analytical information.

The following tasks were considered:

- determination of statistical parameters (mathematical expectation and coefficient of variation) of fatigue resistance of the material and the spring, information about which is mostly absent or contradictory;

- determination of the loading of the springs to failure by the loading spectrum;

- assessment of the probability of failure-free operation and prediction of the spring resource.

Presentation of the main material. We consider springs of class I (no-failure operation of at least $10^{7}$ loading cycles), discharge 1 , in appearance - single-core, tension and compression. Use spring material to choose alloyed resource-spring steels with high requirements for fatigue strength.

Information on the statistical parameters of fatigue resistance of alloyed steels at tangential stresses is ambiguous. In the absence of reliable experimental data on the mathematical expectation of the material fatigue limit during torsion, $\bar{\tau}_{-1}$ is recommended to determine directly from the normal stresses $\bar{\sigma}_{-1}$ [11] using the relation $\tau_{-1}=0.6 \sigma_{-1}$. Pre-applying the empirical formula of the form:

$$
\sigma_{-1}=\left(0.55-0.0001 \sigma_{V}\right) \sigma_{V},
$$

where $\sigma_{V}$ - strength limit of the material (in the absence of information about $\sigma_{V}$ we use dependence $\sigma_{V}=\sigma_{T} / 0.88$, where $\sigma_{T}$ is the limit of yield strength of the material). 
In the spring calculations for fatigue, the transition according to the characteristics of fatigue from the material $\bar{\tau}_{-1}$ to the part $\bar{\tau}_{-1 D}$ is performed according to the standard procedure [12]:

$$
\bar{\tau}_{-1 D}=\frac{\bar{\tau}_{-1}}{K},
$$

where $K$ - the total coefficient of influence, determined by the formula:

$$
K=\left(\frac{k_{\tau}}{k_{d \tau}}+\frac{1}{k_{F \tau}}-1\right) \frac{1}{k_{v} k_{A}} .
$$

The coefficients $k_{\tau}, k_{d \tau}, k_{F \tau}, k_{v}$ and $k_{A}$ in characterize the effect of tangential stress concentration, scale factor, surface treatment quality, surface hardening and material anisotropy, respectively.

Concentration factors are usually established experimentally by the ratio of the fatigue limits of smooth samples $\tau_{-1}$ and samples with a stress concentration $\tau_{-1 D}$ like $k_{\tau}=\tau_{-1} / \tau_{-1 D}$. When they are unavailable in the calculations, the use of the formula [11] is allowed:

$$
k_{\tau}=1+q_{\tau}\left(\alpha_{\tau}-1\right),
$$

where $q_{\tau}$ - coefficient of sensitivity of the metal to the concentration of tangential stresses (for alloyed steels varies in the range $\left.q_{\tau}=0.7 \ldots 0.9\right) q_{\sigma}$;

$\alpha_{\tau}$ - theoretical concentration ratio (the choice $\alpha_{\tau}$ is carried out according to the recommendations [12]).

The values of the sensitivity coefficients of the metal to the concentration of normal stress can also be calculated by the conditions:

$$
\begin{gathered}
q_{\sigma}=0.211-0.000143 \sigma_{V} \text { at } \sigma_{V} \leq 1300 \mathrm{MPa}, \\
q_{\sigma}=0.025 \text { at } \sigma_{V}>1300 \mathrm{MPa} .
\end{gathered}
$$

With torsion we have approximately $q_{\tau}=1.5 q_{\sigma}$.

The coefficient for alloyed steels is determined by the formula [12]:

$$
\begin{gathered}
k_{d \tau}=1-0.2 \lg \frac{d}{d_{o}} \quad \text { at } \quad d \leq 150 \mathrm{~mm}, \\
k_{d \tau}=1 \text { at } d \leq 150 \mathrm{~mm},
\end{gathered}
$$

where $d_{o}=7.5 \mathrm{~mm}$ - diameter of a smooth laboratory specimen.

Empirical dependence of the form is also allowed:

$$
k_{d \tau}=\frac{1}{0.8127+0.0676 d-0.0042 d^{2}},
$$

where $d$ - bar diameter in sm.

On the surface of the material bar for the springs, an oxide film and individual drawing risks are allowed, the depth of which is governed by the technical conditions of rolled alloyed structural steel. Quantitatively, the influence of surface quality on the fatigue limit is measured by the formulas:

$$
\begin{gathered}
k_{F_{\sigma}}=1-0.22 \lg R_{Z}\left(\lg \frac{\sigma_{V}}{20}-1\right) \text { at } R_{Z}>1 \mu \mathrm{m}, \\
k_{F_{\sigma}}=1 \text { at } R_{Z}>1 \mu \mathrm{m}, \\
k_{F_{\tau}}=0.575 k_{F_{\sigma}}+0.425
\end{gathered}
$$

and

where $R_{Z}$ - bar surface roughness. 
The coefficient $k_{v}$ is equal to the ratio of the fatigue limit of the part with surface hardening $\sigma_{-1 \text { Dupr }}$ and without hardening $\sigma_{-1 D}$. According to the recommendations [13], the following values $k_{v}$ are set: 1.0 - without hardening the spring bar hardening; 1.15 - in the presence of work hardening.

Detailed information on the choice of the coefficient $k_{v}$ for different types of processing depending on the sample diameter and the presence of stress concentration is given in [11]. In accordance with the technology of manufacturing springs should be taken $k_{v}=1.15$.

The anisotropy coefficient $k_{A}$ in the calculations of small springs due to the small diameter of the rod can be neglected.

Evaluation of the fatigue limits of the parts indicates their significant scattering. The reasons for this are the structural heterogeneity of the material of one heat, the scattering of mechanical characteristics in different heats, random changes in the modes of mechanical and heat treatment, size dispersion, random deviations from the design forms. In the absence of data from fatigue tests, the total coefficient of variation of the fatigue limit of a part can be calculated using the formula [11]:

$$
v_{\tau_{-1 D}}=\sqrt{v_{\tau_{\max }}^{2}+v_{\tau_{-1}}^{2}+v_{\alpha_{\tau}}^{2}}
$$

where $v_{\tau_{\max }}, v_{\bar{\tau}-1}$ and $v_{\alpha_{\tau}}$ - coefficients taking into account variations in the maximum stresses in the zone of concentration, average (in one heat) values of the fatigue limits of smooth laboratory samples and the theoretical coefficient of stress concentration $\alpha_{\tau}$.

Given the experience of calculations and strength tests, it is recommended to assign in the first approximation $v_{\tau_{\max }}=0.06 \ldots 0.1$. Given the linear relationship between the fatigue limits and the strength of the material, it is assumed that $v_{\bar{\tau}-1}=v_{\tau V}$, where $v_{\tau V}$ is the coefficient of variation of the tensile strength of the metal over the set of all heats.

For alloyed steels, $v_{\sigma V}$ is on average within $0.04 \ldots 0.10$. The springs of category A are made of rolled products with a special surface finish of the wire according to the roughness parameter and permissible surface defects not worse than the processing group $\Gamma$ with maximum diameter deviations from the nominal size not exceeding the quality level 11 (for $d \leq 3 \mathrm{~mm}$ deviations are 60 microns). Since the tolerance on the diameter with the adopted manufacturing technology is insignificant, the influence of $v_{\alpha_{\tau}}$ can be neglected.

Statistical characteristics of loading parts in operation are determined mainly by the results of strain gauging on the existing loading spectra. The load realizations presented are statistically processed by schematization of the obtained operating load curves, i.e., they replace the actual nonstationary loading mode with an equivalent steady-state load, which is called equivalent in fatigue effect. Analytically, the value of the equivalent load is calculated by the formula:

$$
F_{\text {ekv }}=K_{D} F_{\max },
$$

where $K_{D}$ - reduction coefficient.

For the step loading graph in the form of a cyclogram with $n$ steps, we have:

$$
K_{D}=\sqrt[m]{\sum_{1}^{n}\left(\frac{F_{i}}{F_{\max }}\right)^{m} \frac{N_{i}}{N_{o}}},
$$

for continuous loading schedule -

$$
K_{D}=\sqrt[m]{\frac{1}{N_{o}} \int_{N_{o}}^{N_{p}} f\left(\frac{F_{i}}{F_{\max }}\right)^{m} d N_{i}},
$$

where $F_{\max }$ and $F_{i}$ - maximum load, and load at the current $i$-th level (step) of loading;

$N_{i}$ and $N_{p}$ - the number of loading cycles corresponding to the load $F_{i}$ and to the specified resource; 
$m$ and $N_{o}$ - the exponent of the fatigue curve equation and the number of loading cycles corresponding to the inflection point of the fatigue curve;

$f$ - load change law $F_{i}$ over time.

Experience shows that the histograms of the distribution of current values of loads allow a priori to assume the assumption of a normal law, and according to information in [14], the numerical value of the coefficient of load variation $v_{F}$ for individual branches of mechanical engineering is within 0.1...0.15.

The equivalent shear stresses in the spring section are determined by the formula of the form:

$$
\tau_{e k v}=k \frac{8 F_{e k v} D}{\pi d^{3}},
$$

where $k$ - the coefficient of curvature of the coils of the spring, taking into account the additional stress from the action of transverse force and stress concentration. For springs from a rod of circular cross section with index $C=(D / d) \geq 4$, the following formula is used:

$$
k=\frac{4 C-1}{4 C+1}+\frac{0.615}{C} .
$$

Given the linear relationship $F_{e k v}$ and $\tau_{e k v}$ in (12), it is allowed in the calculations to equate the coefficients of variation of amplitudes of the stresses of the $v_{a}$ and the equivalent load of the $v_{F}$.

Statistical characteristics of loads and spring fatigue resistance are used in assessing its reliability by the probability of trouble-free operation $p(t)$. The quantile of the normal distribution is calculated [14]:

$$
u_{p}=-\frac{1-n}{\sqrt{n^{2} v_{-1 D}^{2}+v_{a}^{2}}},
$$

where $n=\left(\bar{\tau}_{-1 D} / \bar{\tau}_{e k v}\right)$ - safety factor based on average fatigue limit and spring load amplitude. The value $u_{p}$ calculated from (14) makes it possible to determine the probability of spring failure-free operation $p(t)$ using the tables [14].

According to the above calculation, the reliability of the springs is established without the characteristic of their fatigue longevity, which makes it impossible to pre-set their resource. By fatigue cyclic longevity, we understand the resource $N_{p}$, as the total number of loading cycles in case of failure-free operation of the spring to fatigue failure. To estimate the spring resource, the Weller equation is used, which, as applied to shear stresses, takes the form:

$$
\tau_{e k v}^{m} N_{p}=\tau_{-1 D}^{m} N_{o} .
$$

Then the calculated cyclic longevity of the spring is calculated as:

$$
N_{P}=N_{o}\left(\frac{\tau_{-1 D}}{\tau_{e k v}}\right)^{m} \text {. }
$$

When choosing $N_{o}$ and $m$ for alloyed steels, the information in [13] is used.

To estimate the spring resource in the clock, the following formula is used:

$$
T=\frac{N_{p}}{60 n},
$$

where $n$ - the number of spring loading cycles per minute, depending on the working conditions.

The value $T$ calculated from (17) corresponds to a probability of $50 \%$. When determining $T_{P}$ with a given probability $P$, in the assumption of a normal distribution law, the following dependence is used:

$$
\lg T_{P}=\lg \bar{T}+u_{p} S_{\lg T},
$$

where $s_{\lg T}$ - the standard deviation of the logarithm of the longevity (resource) of the spring in hours. 
Let us consider an example of a test calculation for the fatigue strength of a compact cylindrical helical spring of tension and compression, whose geometric, elastic, and force parameters are calculated and selected based on the results of the design calculation.

Baseline: Class I spring; single core; stretching and compression; position 366 (bar diameter $d=2 \mathrm{~mm}$; outer spring diameter $D=14 \mathrm{~mm}$ ); Bar material - alloyed steel 50ХФA. The calculation is performed on the tangential stress in the probabilistic aspect.

For the selected calibrated bar of long products Wire 50ХФА-К-1А-П-Д-2 according to the condition of delivery and heat treatment, we have the following limit values: strength $\sigma_{V}=1270 \mathrm{MPa}$; fluidity $\sigma_{T}=1080 \mathrm{MPa}$; bending fatigue with symmetric load cycle $\sigma_{-1}=676$; 686 and $725 \mathrm{MPa}$ (depending on heat treatment). Since the information on the limits of material fatigue is contradictory, the value $\bar{\tau}_{-1}$ was determined analytically. By the formula (1) with $\sigma_{V}=1270 \mathrm{MPa}$, we have $\sigma_{-1}=537 \mathrm{MPa}$, and then $\tau_{-1}=0.6 \sigma_{-1}=0.6 \cdot 537=322 \mathrm{MPa}$.

The spring fatigue limit $\bar{\tau}_{-1 D}$ was calculated by the formula (2), having previously determined the coefficient of multifactor influence. For a cylindrical spring bar it is recommended to take $\alpha_{\tau}=1$. The coefficient $k_{d \tau}$ is determined using the formula (7) for alloyed steels: when $d=0.2 \mathrm{sm}$, we have $k_{d \tau}=1.21$.

According to the table. [11] when $d=2 \mathrm{~mm}$, we get $k_{d \tau}=1.209$, which confirms the correctness of the previous calculation of the indicator. In accordance with the supply of wire group A have a class 9 roughness $\left(R_{Z}=2.6 \ldots 0.8 \mu \mathrm{m}\right)$. With the substitution in (7) and (8) $R_{Z} \leq 2.6 \mu \mathrm{m}, k_{F_{\sigma}}=0.927$ were obtained and $k_{F_{\tau}}=0.958$. According to the technology of manufacturing springs and recommendations [11], we assume $k_{v}=1.15$. The anisotropy coefficient $k_{A}$ is neglected.

After substituting the calculated and accepted values of the coefficients into (3), we have $K=0.757$. Usually in calculations $K=1.5 \ldots 3$.

The discrepancy is because the diameter of the wire $d$ less than the diameter of the laboratory sample $d_{o}$ for which determine the tensile strength, unlike most real-world parts.

Decrease $K$ also contributes to the technology of making wire for springs.

To determine the overall coefficient of variation of the spring fatigue limit, we calculated the components that are included in formula (9). From the limits $v_{\tau_{\max }}=0.06 \ldots 0.1$, according to recommendations [12], it was chosen $v_{\tau_{\max }}=0.08$. Since it is assumed that $v_{\bar{\tau}-1}=v_{\tau V}$, and for alloy steels $v_{\sigma V}$, it is in the range of $0.04 \ldots 0.10, v_{\bar{\tau}-1}=0.07$ was used in the calculations. It was previously proved that $v_{\alpha_{\tau}}=0$. Finally, by (9), we determined $v_{\tau-1 D}=0.106$.

According to the results of processing a statistical series of random values of loads determined experimentally, the following parameters were obtained: the mathematical expectation of an equivalent load of $\bar{F}_{e k v}=75.47 \mathrm{~N}$ and the coefficient of variation of the load was $v_{F}=0.121$, which is within the allowable limits of 0.1...0.15.

The equivalent tangential stresses in the spring section were calculated by the formula (12): with the spring index $C=(D / d) \geq 4$ and the spring curvature coefficient $k=1.02$, we obtained $\tau_{e k v}=343.2 \mathrm{MPa}$. The coefficient of variation of the voltage amplitudes equated to the coefficient of variation of the equivalent load $v_{F}$, i.e., $v_{a}=0.121$.

The safety factor was calculated $n=\left(\bar{\tau}_{-1 D} / \bar{\tau}_{\text {ekv }}\right)=1.238$ and when substituting the previously calculated values in (14), we obtained $u_{p}=-1.333$. According to the table, found the probability of trouble-free springs: $p\left(u_{p}=-1.333\right)=0.908$.

When calculating the cyclic longevity of the spring made of alloyed steel 50XФA, it is recommended to take $N_{o}=2.16 \cdot 10^{6}$ cycles and $m=12.8$ [13]. Using formula (18), the spring cycle life will be $N_{p}=3.32 \cdot 10^{7}$ loading cycles. Resource $T_{p}$ in hours depends on the mode of operation of the spring. 
Conclusions. A methodological complex for assessing and ensuring fatigue longevity and reliability of compact cylindrical helical springs according to the fatigue strength criterion in a high-cycle loading area using materials of regulatory guidance documents, empirical and analytical information is proposed.

Depending on the resource at the design stage and finishing the node, the results of problem solving make it possible to identify the optimal design and technical options that provide the greatest longevity and reliability with the smallest spring dimensions.

\section{Литература}

1. Aimin Y., Changjin Y. Formulation and evaluation of analytical studies for cylindrical helical spring. Acta Mechanica Solida Sinica. 2010. Vol. 23, № 1. P. 85-94.

2. Канарчук В.С., Полянський С.К., Дмитрієв М.М. Надійність машин. Київ: Либідь, 2003. 424 с.

3. Dammak F. Finite element method for the stress analysis of isotropic cylindrical helical spring. European Journal of Mechanics A Solids. 2005. Vol. 24, № 6. P. 1068-1078.

4. Fatigue behavior of helical compression springs at a very high number of cycles - Investigation of various influences / B. Pyttel, I. Brunner, B. Kaiser, C. Berger, M. Mahendran. International journal of fatigue. 2014. Vol. 60. P. 101-109.

5. Berger C., Kaiser B. Results of very high cycle fatigue tests on helical compression springs. International journal of fatigue. 2006. Vol 28, № 12. P. 1658-1663.

6. Investigation of probable failure position in helical compression springs used in fuel injection system of engines / B. Pyttel, K. Ray, I. Brunner, A. Tiwari, S. Kaoua. Journal of Mechanical and Civil Engineering. 2012. Vol. 2, № 3. P 24-29.

7. Kaiser B., Pyttel B., Berger C. Behavior of helical compression springs made of different materials. International journal of fatigue. 2011. Vol. 33, № 1. P. 23-32.

8. Das A., Kumar A. Selection of Spring Material Using Promethee Method. Journal of Mechanical and Civil Engineering. 2015. Vol. 12, № 5. P. 82-91.

9. Failure Analysis of an Automobile Coil Spring in High-Stress State / Y. Shuaijiang, W. Qingxiang, C. Xing, Z. Chengsong, C. Guodong. Journal of Failure Analysis and Prevention. 2019. Vol. 19, № 2. P. 361-368.

10. Failure analysis of cylinder head valve spring in locomotives / G. Moorthy, S. Balakrishnan, S. Chitharthan, K. Ranjith. International Research Journal of Engineering and Technology. 2017. Vol. 4, № 3. P.124-130.

11. Когаев В.П., Дроздов Ю.Н. Прочность и износостойкость деталей машин: справочник. Москва, $1991.319 \mathrm{c}$.

12. ГОСТ 25.504-82. Расчеты и испытания на прочность. Методы расчета характеристик сопротивления усталости. [Дата введения от 1982-06-30]. Москва, 1982. 52 с. (Информация и документация).

13. Сопротивление усталости металлов и сплавов: справочник в 2 т. / В.Т. Трощенко, Л.А. Сосновский. Київ: Наукова думка, 1987. 1315 с.

14. Решетов Д.Н., Иванов А.С., Фадеев В.З. Надежность машин. Москва: Высш. шк., 1988. 238 с.

\section{References}

1. 1Aimin, Y., \& Changjin, Y. (2010). Formulation and evaluation of analytical studies for cylindrical helical spring. Acta Mechanica Solida Sinica, 23, 1, 85-94.

2. Kanarchuk,V. C., Polyanskiy, S. K., \& Dmitriev M. M. (2003). Nadiynist mashyn. Kyiv: Libid.

3. Dammak, F. (2005). Finite element method for the stress analysis of isotropic cylindrical helical spring. European Journal of Mechanics A Solids, 24, 6, 1068-1078.

4. Pyttel, B., Brunner, I., Kaiser, B., Berger, C. \& Mahendran, M. (2014). Fatigue behavior of helical compression springs at a very high number of cycles- Investigation of various influences. International journal of fatigue, 60, 101-109.

5. Berger, C., \& Kaiser, B. (2006). Results of very high cycle fatigue tests on helical compression springs. International journal of fatigue, 28, 12, 1658-1663. 
6. Pyttel, B., Ray, K., Brunner, I., Tiwari, A. \& Kaoua, S. (2012). Investigation of probable failure position in helical compression springs used in fuel injection system of engines. Journal of Mechanical and Civil Engineering, 2, 3, 24-29.

7. Kaiser, B., Pyttel, B., \& Berger, C. (2011). Behavior of helical compression springs made of different materials. International journal of fatigue, 33, 1, 23-32.

8. Das, A., \& Kumar, A. (2015). Selection of Spring Material Using Promethee Method. Journal of Mechanical and Civil Engineering, 12, 5, 82-91.

9. Shuaijiang, Y., Qingxiang, W., Xing, C., Chengsong, Z., \& Guodong, C. (2019). Failure Analysis of an Automobile Coil Spring in High-Stress State. Journal of Failure Analysis and Prevention, 19, 2, 361-368.

10. Moorthy, G., Balakrishnan, S., Chitharthan, S., \& Ranjith, K. (2017). Failure analysis of cylinder head valve spring in locomotives. International Research Journal of Engineering and Technology, 4, 124-130.

11. Kogaev, V. P., \& Drozdov, Yu. N. (1991). Durability and wear resistance of machine details: Handbook. Moscow: Mechanical engineering.

12. GOST 25.504-82. Strenqth calculation and testinq. Methods of fatique strenqth behaviour calculation. Moscow: Standartinform Publ., 1982. 29 p.

13. Troshchenko, V. T., \& Sosnovskyi, L. A. (1987). Resistance to fatigue of metals and alloys: Handbook. In 4 vols. Vol.1. Kyiv: Naukova dumka.

14. Reshetov, D. N., Yvanov, A. S., \& Fadeev, V. Z. (1988). Reliability of machines. Moscow: High school.

Березін Леонід Миколайович; Berezin Leonid, ORCID: http:// orcid.org/ 0000-0002-2672-6323 